\title{
Polycyclic aromatic hydrocarbons: levels and phase distributions in preschool microenvironment
}

\author{
M. Oliveira, K. Slezakova, \\ C. Delerue-Matos ${ }^{1}$, M. C. Pereira, S. Morais
}

\begin{abstract}
This work aims to characterize levels and phase distribution of polycyclic aromatic hydrocarbons (PAHs) in indoor air of preschool environment and to assess the impact of outdoor PAH emissions to indoor environment. Gaseous and particulate $\left(\mathrm{PM}_{1}\right.$ and $\mathrm{PM}_{2.5}$ ) PAHs (16 USEPA priority pollutants, plus dibenzo[a,1]pyrene, and benzo[j]fluoranthene) were concurrently sampled indoors and outdoors in one urban preschool located in north of Portugal for 35 days. The total concentration of 18 PAHs ( $\Sigma$ PAHs) in indoor air ranged from 19.5 to $82.0 \mathrm{ng} / \mathrm{m}^{3}$; gaseous compounds (range of 14.1 $66.1 \mathrm{ng} / \mathrm{m}^{3}$ ) accounted for $85 \% \Sigma$ PAHs. Particulate PAHs (range $0.7-15.9 \mathrm{ng} /$ $\mathrm{m}^{3}$ ) were predominantly associated with $\mathrm{PM}_{1}(76 \%$ particulate $\Sigma \mathrm{PAHs})$ with 5ring PAHs being the most abundant. Mean indoor/outdoor ratios $(\mathrm{I} / \mathrm{O})$ of individual PAHs indicated that outdoor emissions significantly contributed to PAH indoors; emissions from motor vehicles and fuel burning were the major sources.
\end{abstract}

\section{Practical Implications}

This study fills a gap providing information on levels and phase distribution (gas, and $\mathrm{PM}_{1}$ and $\mathrm{PM}_{2.5}-$ bound) of polycyclic aromatic hydrocarbon (PAHs) in preschool educational settings. Despite the current concerns about regulations of indoor pollutants, there is lack of studies on indoor and outdoor PAHs in education settings; in addition, no study reported information about PAHs in the finest fractions of particulates (such as $\mathrm{PM}_{1}$ ) in schools or preschools. The high proportion of PAHs detected in the gas phase clearly demonstrates that adequate assessment of PAHs exposure requires consideration of the gaseous compounds, which are commonly neglected.

\section{Introduction}

Polycyclic aromatic hydrocarbons (PAHs) are organic contaminants characterized by the presence of at least two fused aromatic rings. These compounds are ubiquitous environmental pollutants that are released from combustion sources such as coal burning power plants, diesel- and gasoline-powered vehicles, home heating, 
and waste treatment (Hanedar et al., 2014; Ravindra et al., 2008; Slezakova et al., 2013b). An important aspect of air quality management is identification of indoor PAH sources. Cooking, secondhand cigarette smoke, as well as the penetration of outdoor particulate and vapor phase PAHs into buildings (through windows, doors, cracks, and ventilation system) have been recognized as major contributors to the indoor PAH air pollution (Chen et al., 2012; Qi et al., 2014; Shen et al., 2012; Slezakova et al., 2014). Health effects of PAHs exposure have been widely studied (AnnesiMaesano et al., 2007; Bae et al., 2010; Tuntawiroon et al., 2007), primarily because of their potential carcinogenic and mutagenic properties. Some PAHs are classified as persistent organic pollutants (WHO, 2013), and 16 of them are regarded as priority pollutants by the US Environmental Protection Agency (USEPA, 2005). Several of the PAHs are referred to as endocrine disrupting chemicals, with the most wellknown marker of PAHs being benzo[a]pyrene (WHO, 2013). Benzo[a]pyrene is considered by International Agency for Research on Cancer (IARC) as carcinogenic to humans (group 1) (IARC 2010), whereas several other PAHs are classified as probably and possibly carcinogenic to humans (groups $2 \mathrm{~A}$ and $2 \mathrm{~B}$, respectively).

Benzo[a]pyrene is often used as a surrogate for other carcinogenic PAHs in studies estimating human cancer risks. There have been also efforts to regulate PAHs levels in air. Using benzo[a]pyrene as indicator of carcinogenic PAHs, current European legislation on ambient air (Directive 2004/107/EC) sets annual target value of $1 \mathrm{ng} / \mathrm{m}^{3}$ for carcinogenic PAHs in $\mathrm{PM}_{10}$. However, findings about the presence of more potent PAHs, such as dibenzo[a,l]pyrene and dibenz[a,h] anthracene (Okona-Mensah et al., 2005) have raised some questions concerning the suitability of this approach (Pufulete et al., 2004). In that regard, the evaluation of PAHs in the smallest particulate fraction, such as $\mathrm{PM}_{1}$ and $\mathrm{PM}_{2.5}$, is health relevant because of the ability of these particles to deposit deeply in the respiratory airways; the epidemiological evidence indicates that these smaller particles may have a greater potency in causing adverse health effects than larger particles.

The impact of indoor air pollution on child's health is one of the key focuses of many international organizations. Children spend per day approximately 7-8 h of their time (i.e., $30 \%$ ) at premises of the education settings (i.e., preschools and schools), which raises interest in characterizing health relevant pollutants in these environments. Children breathe higher volumes of air relative to their body weights than adults do. As their physiological and immunological systems are not fully developed, in respect to air quality children represent one of the most sensitive groups of the society (Burtscher and Schüepp, 2012; Ginsberg et al., 2008).
The studies show that health impact of air pollutants is much higher on pupils than on adults in similar environments (Guo et al., 2010). Thus, children are more likely to suffer the consequences of indoor pollution (Alves et al., 2014). Despite the current concerns about indoor pollutants, there is lack of studies on indoor and outdoor PAHs in educational settings; in addition, no study has reported information about PAHs in the finest fractions of particulate matter (such as $\mathrm{PM}_{1}$ ) in schools or in preschools. Numerous individual PAH compounds, time-consuming and financially demanding analytical methodology, as well as the complex formation mechanisms have resulted in studies primarily focused on the outdoor air. A better understanding on indoor PAHs may lead to further recommendations for air quality improvements and potentially to review existent air quality guidelines. Furthermore, the characterization of particulate and gas-phase PAHs indoors and outdoors of schools is of great importance, as it may allow lowering health risks for children.

Thus, the aim of this study was to investigate indoor levels of particulate $\left(\mathrm{PM}_{1}\right.$ and $\left.\mathrm{PM}_{2.5}\right)$ and gaseous PAHs (16 considered by USEPA as priority pollutants, and dibenzo[a,l]pyrene and benzo[j]fluoranthene; the latter recommended by EU Directive $2004 / 107 /$ EC) at a preschool in Oporto, Portugal. The phase distribution of indoor PAHs was characterized and the impact of outdoor PAH emissions to indoor environment was assessed. In addition, diagnostic ratios were applied to identify possible emission sources of indoor PAHs.

\section{Material and methods}

Characterization of the sampling site

Sixteen PAHs considered by USEPA as priority pollutants, plus dibenzo[a,1]pyrene and benzo[j]fluoranthene were sampled in air (gas and particulate phases) for 35 consecutive days during February-April 2011 at one preschool situated in the urban zone of Oporto, Portugal. Preschools are educational establishments that provide education for 3- to 5-year-old children, prior to the beginning of compulsory attendance at primary schools. Specifically in Portugal 'preschools' refer to institutions that are directly operated by primary schools. The selected preschool was situated in Oporto Metropolitan Area, in Paranhos district (north of Portugal); previously it was demonstrated that emissions from vehicular traffic contributed the main pollution source in this area (Slezakova et al., 2013a,b). The detailed description of the preschool and its characteristics are shown in Table 1.

To better understand the impacts of outdoor PAH emissions to an indoor preschool environment, the 
Table 1 Characterization of the studied preschool, meteorological and indoor and outdoor air pollution conditions during the sampling campaign

\begin{tabular}{|c|c|}
\hline \multirow[t]{4}{*}{ General description } & Built in 1940 \\
\hline & Private school \\
\hline & Two-floors building \\
\hline & 173 enrolled students: $3-5$ years old \\
\hline \multirow[t]{2}{*}{ Location } & Urban-traffic \\
\hline & Situated on moderately trafficked streets \\
\hline \multirow[t]{3}{*}{ Traffic density } & Mean: 16 cars/min \\
\hline & Peak hours: 8:30 h (27 cars/min) \\
\hline & $18: 30$ h $(25$ cars $/ \mathrm{min})$ \\
\hline \multirow[t]{2}{*}{ Indoor parameters } & Temperature: $18.2 \pm 1.1{ }^{\circ} \mathrm{C}$ \\
\hline & Relative humidity: $58.7 \pm 9.0 \%$ \\
\hline Indoor pollutants levels & a \\
\hline \multirow{3}{*}{ Mean (Min-Max) $\left(\mathrm{mg} / \mathrm{m}^{3}\right)$} & TVOCs: 2.7 (0.60-4.5) \\
\hline & $\mathrm{CO}_{2}: 2340(1360-3400)$ \\
\hline & CO: 1.0 (n.d-2.8) \\
\hline \multirow[t]{2}{*}{ Mean $(\operatorname{Min}-\operatorname{Max})\left(\mu \mathrm{g} / \mathrm{m}^{3}\right)$} & Formaldehyde: 184 (n.d.-479) \\
\hline & Ozone: $0.13\left(9.0 \times 10^{-2}-0.18\right)$ \\
\hline \multirow{5}{*}{$\begin{array}{l}\text { Outdoor meteorological parameters } \\
\text { Mean } \pm \text { s.d. }\end{array}$} & Temperature: $13.0 \pm 2.4{ }^{\circ} \mathrm{C}$ \\
\hline & Relative humidity: $73.0 \pm 16 \%$ \\
\hline & Wind speed: $4.5 \pm 2.4 \mathrm{~km} / \mathrm{h}$ \\
\hline & Precipitation: $2.9 \pm 3.0 \mathrm{~mm}$ \\
\hline & Solar radiation: $162 \pm 53 \mathrm{~W} / \mathrm{m}^{2}$ \\
\hline \multirow{3}{*}{$\begin{array}{l}\text { Outdoor pollution parameters }\left(\mu \mathrm{g} / \mathrm{m}^{3}\right) \\
\text { Mean (Min-Max) }\end{array}$} & $\mathrm{PM}_{10}: 33(6-80)$ \\
\hline & NO: 148 (30-1370) \\
\hline & C0: 981 (314-1560) \\
\hline
\end{tabular}

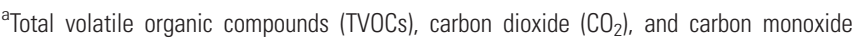
(CO).

${ }^{b}$ Figures in parenthesis represent concentration ranges of $24 \mathrm{~h}$ means during the sampling campaign as settled in EU air quality legislation (Directive 2008/50EC).

levels of PAHs were concurrently measured in outdoor air.

The traffic densities were estimated for the streets surrounding the preschool (Table 1). During two consecutive days, the number of road vehicles, namely passenger cars, trucks/buses, motorbikes and others, was manually counted between 5 a.m. and 12 p.m. during 10 min of each hour. These data were used to better describe the surroundings of the selected preschool.

\section{Sample collection}

Both gaseous and particulate samples were collected daily for a period of $24 \mathrm{~h}$. During the sampling campaign, 105 daily samples of particulate and gas phases were collected. The sampling equipment was placed indoors in a common room that was used throughout day both for educational and entertaining activities as well as for physical exercising. The room layout and its characteristic are shown in Figure S1 and Table S1 of the Supplementary material, respectively. The sampling was done by constant flow samplers (model Bravo H2; TCR TECORA, Milan, Italy) that were combined with PM EN LVS sampling heads for gaseous and particulate samples (in compliance with norm EN14907 for $\mathrm{PM}_{2.5}$, and $\mathrm{PM}_{1}$ ); an airflow rate of $2.3 \mathrm{~m}^{3} / \mathrm{h}$ was used. The inlets were positioned at $1.5 \mathrm{~m}$ above the floor and minimally $1 \mathrm{~m}$ from the walls, without obstructing the normal usage of the rooms. The samplers were located as far as possible from windows or doors to minimize direct influence of any source. All requirements to maintain child safety were fulfilled. Concurrently, $\mathrm{PM}_{2.5}$-bound PAHs were measured in outdoor air at preschool yard, a safe distance from areas with children's intense activity. The samplers were positioned in open area avoiding any obstacles and barriers (trees, bushes walls, and fences) that could interfere with data collection. The distance from the main street was $8 \mathrm{~m}$.

The different fractions of particles, that is, $\mathrm{PM}_{2.5}$ and $\mathrm{PM}_{1}$, were collected on polytetrafluoroethylene (PTFE) membrane filters with polymethylpentene support ring ( $2 \mu \mathrm{m}$ porosity, $\varnothing 47 \mathrm{~mm}$; SKC Ltd., UK). Gaseous samples were collected on polyurethane foam (PUF) plugs (75 mm; SKC Ltd.) that were pre-cleaned using the procedure of Castro et al. (2011).

Indoor temperature $(\mathrm{T})$ and relative humidity $(\mathrm{RH})$ were measured using Testo mini data-logger (model 174H; Testo AG, Lenzkirch, Germany), which operated continuously with a logging interval of $10 \mathrm{~min}$. Other indoor pollutants were also measured (Table 1). The concentrations of carbon monoxide $(\mathrm{CO})$, carbon dioxide $\left(\mathrm{CO}_{2}\right)$, total volatile organic compounds (TVOCs), and ozone $\left(\mathrm{O}_{3}\right)$ were performed by multigas sensor probe (model TG 502; GrayWolf Sensing Solutions, Shelton, USA) that was daily calibrated. The measurements were conducted 2-3 for each school day (both in morning and afternoon), each time for 15-20 min (with a logging interval of $30 \mathrm{~s}$ ). In addition, the levels of formaldehyde were registered with Formaldemeter $^{\mathrm{TM}}$ (model htV-M; PPM Technology, Caernarfon, UK) following the same methodology as for other indoor pollutants.

Information on outdoor meteorological conditions, namely $\mathrm{T}, \mathrm{RH}$, wind speed (WS), precipitation (P), and solar radiation (SR) were retrieved from the local meteorological stations and are summarized in Table 1.

During sample collection, a researcher was present to keep a record of room occupancy, potential source activities, and ventilation system status (door and window positions). During the sampling campaign, the room was intensively ventilated twice per day by opening of all windows: approximately for 15-20 min before children arrivals (around 7:30 a.m.) and at the end of the day when everybody left and the room was empty (after 6:0 p.m., for approximately $15 \mathrm{~min}$ ); throughout the rest of days and during nights windows were always kept closed. Doors were always maintained closed during the educational activities (classes) and physical activities; during recesses and periods with recreational activities they were opened. In addition, teachers and staff were asked daily regarding the occurrence of any additional source or activities that might influence the monitored parameters. 
$\mathrm{PM}_{2.5}$ and $\mathrm{PM}_{1}$ masses

$\mathrm{PM}_{2.5}$ and $\mathrm{PM}_{1}$ masses were determined gravimetrically according to Slezakova et al. (2014). The steps of gravimetric mass determination were the following: $24 \mathrm{~h}$ to equilibrate filters before weighing at room temperature (Mettler Toledo AG245 analytical balance weighing with accuracy of $10 \mu \mathrm{g}$ ) followed by weighing during the following 24-48 h. If the measurements for one sample differed more than $10 \mu \mathrm{g}$, they were discarded and the filters were repeatedly weighed until three reproducible values were obtained. The filters were then kept in Petri dishes. After the sampling both filters and PUF plugs were stored in a freezer $\left(-20^{\circ} \mathrm{C}\right)$ before consequent chemical analysis.

\section{Extraction and chromatographic analysis of PAHs}

The extractions of PAHs from particles $\left(\mathrm{PM}_{2.5}\right.$ and $\mathrm{PM}_{1}$ ) and PUF plugs were performed by previously validated analytical procedure (Castro et al., 2009, 2011). Briefly, filters and PUF plugs were microwaveassist extracted with 30 and $45 \mathrm{ml}$ of acetonitrile, respectively, for $20 \mathrm{~min}$ at $110^{\circ} \mathrm{C}$. After extraction, the vessels were allowed to cool at room temperature; extracts were then carefully filtered through a PTFE membrane filter $(0.45 \mu \mathrm{m})$ and reduced to a small volume using a rotary evaporator (Rotavapor ${ }^{\circledR}$, R-200; BUCHI, Flawil, Switzerland) at $20{ }^{\circ} \mathrm{C}$. A gentle stream of nitrogen was used to dry the extracts under low temperature; the residue was then dissolved in $1000 \mu$ of acetonitrile immediately before analysis.

To quantify PAHs, extracts were analyzed using a Shimadzu LC system (Shimadzu Corporation, Kyoto, Japan) equipped with a LC-20AD pump, DGU-20AS degasser and photodiode array SPD-M20A (PAD) and fluorescence RF-10AXL (FLD) detectors (Castro et al., 2009, 2011). Separation of the compounds was performed in a C18 column (CC 150/4 Nucleosil 100-5 $\mathrm{C} 18 \mathrm{PAH}, 150 \times 4.0 \mathrm{~mm} ; 5 \mu \mathrm{m}$ particle size; Macherey-Nagel, Duren, Germany) maintained at room temperature $\left(20 \pm 1{ }^{\circ} \mathrm{C}\right)$. The injected volume was $15.0 \mu \mathrm{l}$. A mixture of water and acetonitrile was used as the mobile phase. The initial composition of the mobile phase was $50 \%$ of acetonitrile and $50 \%$ ultrapure water, and a linear gradient to $100 \%$ of acetonitrile was programmed in $15 \mathrm{~min}$, with a final hold of $13 \mathrm{~min}$. Initial conditions were reached in $1 \mathrm{~min}$ and maintained for 6 min before next run. The total run time was $40 \mathrm{~min}$ with a flow rate of $0.8 \mathrm{ml} / \mathrm{min}$. Fluorescence wavelength programming was used to achieve better sensitivity and minimal interference. Each compound was detected at its optimum excitation/emission wavelength pair: $260 / 315 \mathrm{~nm}$ (naphthalene, acenaphthene and fluorene), 260/366 nm (phenanthrene), 260/430 nm (anthracene, fluoranthene, pyrene, benz[a]anthracene, chrysene, benzo $[\mathrm{b}+\mathrm{j}]$ fluoranthene, benzo[k]fluoranthene, benzo[a]pyrene, dibenz[a,h]anthracene, benzo[ghi]perylene and dibenzo [a,1]pyrene), and 290/505 nm (indeno[1,2,3-cd]pyrene). Acenaphthylene, which shows limited fluorescence, was analyzed at $254 \mathrm{~nm}$ in the PAD. Each analysis was performed at least in triplicate.

\section{Quality control}

The overall MAE-LC procedure for analysis of PAHs in atmospheric particulate samples was previously validated by systematic recovery experiments and analyzing the certified reference material SRM 1650b 'Diesel particulate matter' (Castro et al., 2009). PAHs were extracted from particles with recoveries ranging from $81.4 \pm 8.8 \%$ to $112.0 \pm 1.1 \%$, for all the compounds except for naphthalene $(62.3 \pm 18.0 \%)$ and anthracene $(67.3 \pm 5.7 \%)$. The validation of MAE procedure for extracting PAHs from PUFs was performed according to Castro et al. (2011). The extraction efficiency was consistent over the entire range of concentrations and the results ranged from $50.2 \pm 3.5 \%$ (acenaphthylene) to $107.9 \pm 1.5 \%$ (fluoranthene) for all PAHs. External calibrations with PAHs mixed standards, using at least six calibration points, were performed. Calibrations curves were linearly fitted with correlation coefficients always higher than 0.9997 for all PAHs. Limits of detection (LODs) and limits of quantification (LOQs) were calculated as the minimum detectable amount of analyte with a signal-to-noise ratio of $3: 1$ and $10: 1$, respectively (Miller and Miller, 2000). LODs between $1.0 \mathrm{pg} / \mathrm{m}^{3}$ (for anthracene, benzo[k]fluoranthene, chrysene, benz [a]anthracene, phenanthrene and indeno[1,2,3-cd]pyrene) and $148 \mathrm{pg} / \mathrm{m}^{3}$ (for acenaphthylene) were obtained, with corresponding LOQs in the range 3.4 $492 \mathrm{pg} / \mathrm{m}^{3}$. During each set of MAE extractions, a filter blank or a PUF plug blank was included. The repeatability was evaluated by the relative standard deviations (RSD) of triplicate samples. RSD values ranged from $1.8 \%$ (dibenzo[a,1]pyrene) to $9.1 \%$ (naphthalene) and from $0.9 \%$ (chrysene) to $9.8 \%$ (naphthalene) for PAHs extraction from filters and PUFs, respectively. Standards used for calibration were analyzed daily and regularly, as well as blank MAE extracts (from filter blank or PUF plug blank), between samples to check instrument performance during PAHs analysis. Each analysis was run at least in triplicate.

\section{Statistical analysis}

For the data treatment, the Student's $t$-test was applied to determine the statistical significance $(P<0.05$, two tailed) of the differences between the means determined for indoor and outdoor samples or for different phases or particle size fractions. 


\section{Results and discussion}

PM and indoor gases

The indoor concentrations of $\mathrm{PM}_{2.5}$ and $\mathrm{PM}_{1}$ ranged, respectively, from 2.1 to $106 \mu \mathrm{g} / \mathrm{m}^{3}$ (mean of $27 \mu \mathrm{g} / \mathrm{m}^{3}$ ) and 1.1 to $82 \mu \mathrm{g} / \mathrm{m}^{3}$ (mean of $24 \mu \mathrm{g} / \mathrm{m}^{3}$ ). On average, a majority of the $\mathrm{PM}_{2.5}$ was comprised of $\mathrm{PM}_{1}$; these particles accounted for $91 \%$ of $\mathrm{PM}_{2.5}$. Furthermore, the outdoor air exhibited similar levels of $\mathrm{PM}_{2.5}$ as indoors, with outdoor concentrations ranging from 5.1 to $113 \mu \mathrm{g} / \mathrm{m}^{3}$ (mean of $29 \mu \mathrm{g} / \mathrm{m}^{3}$ ); the estimated indoor and outdoor means were not significantly different $(P<0.05)$.

The levels of other indoor pollutants are presented in Table 1. The mean of $\mathrm{CO}$ fulfilled the limit of $10 \mathrm{mg} / \mathrm{m}^{3}$ set by current Portuguese legislation for indoor air of public buildings (Decreto Lei 118/2013). $\mathrm{CO}_{2}$ slightly exceeded the limit of $2250 \mathrm{mg} / \mathrm{m}^{3}$. The levels of TVOCs and formaldehyde surpassed (approximately 4.5 and 1.8 times) limit values of 100 and $600 \mu \mathrm{g} / \mathrm{m}^{3}$, respectively. It is necessary to point out that in 2013 Portuguese legislation on indoor air pollution of public buildings was revised. Whereas the limit values of these gas pollutants remained the same, the recommend sampling duration was set to $8 \mathrm{~h}$ instead the previously suggested $5 \mathrm{~min}$ interval (as conducted within this work).

\section{Indoor PAHs}

The levels of indoor PAHs associated with each phase are summarized in Table 2, which shows the indoor mean concentrations (as well as median and interquartile range) of 18 PAHs in $\mathrm{PM}_{2.5}, \mathrm{PM}_{1}$, and in the gasphase at the studied preschool. In agreement with the previous studies on indoor air quality in the Oporto Metropolitan Area (Castro et al., 2011; Slezakova et al., 2009), dibenz[a,h]anthracene was the most abundant indoor particle-bound PAH at the studied preschool. This compound reached mean concentrations of 1.7 and $1.4 \mathrm{ng} / \mathrm{m}^{3}$ in $\mathrm{PM}_{2.5}$ and $\mathrm{PM}_{1}$, respectively, accounting in both PM size fractions for about $30 \%$ of $\Sigma_{\text {PAHs. }}$. The dominance of this compound indicates influence from light-duty gasoline vehicle emissions (Ravindra et al., 2008). The other abundant PAHs in $\mathrm{PM}_{2.5}$ and $\mathrm{PM}_{1}$ were, in descending order, benzo $[\mathrm{b}+\mathrm{j}]$ fluoranthene (approximately 15\%), indeno[1,2,3-cd] pyrene $\left(12-14 \%\right.$ in $\mathrm{PM}_{2.5}$ and $\mathrm{PM}_{1}$, respectively) and benzo[ghi]perylene ( $8 \%$ in $\mathrm{PM}_{2.5}, 10 \%$ in $\left.\mathrm{PM}_{1}\right)$. Naphthalene was the least abundant particle-bound PAH (approximately 2\%); but, in the gas-phase, it was the second most abundant compound $(26 \%$ of gaseous $\Sigma_{\text {PAHs }}$ ) reaching a mean of $7.7 \mathrm{ng} / \mathrm{m}^{3}$. Other abundant gaseous compounds were, in descending order, phenanthrene $\left(32 \%\right.$ of $\left.\Sigma_{\mathrm{PAHs}}\right)$, fluorene $(19 \%)$, and acenapthylene $(13 \%)$. These four PAHs accounted in total for $90 \%$ of indoor gaseous $\Sigma_{\mathrm{PAHs}}$ at the studied pre- school whereas each of the 5-6 ringed compounds accounted approximately for $<0.5 \%$ of gaseous $\Sigma_{\mathrm{PAHs}}$. Regarding the levels of PAHs in air (i.e., sum of PAH levels in $\mathrm{PM}_{2.5}$ and in gas-phase; Table 2), the total concentrations of $18 \mathrm{PAHs}\left(\Sigma_{\mathrm{PAHs}}\right)$ ranged from 20 to $82 \mathrm{ng} / \mathrm{m}^{3}$ with a mean of $35 \mathrm{ng} / \mathrm{m}^{3}$. Specifically, naphthalene reached a mean of $7.8 \mathrm{ng} / \mathrm{m}^{3}$ which is below the WHO recommend annual guideline value of $10 \mu \mathrm{g} /$ $\mathrm{m}^{3}$ (WHO, 2010). Krugly et al. (2014) observed naphthalene levels in similar ranges in five elementary schools in Lithuania (medians between 12 and $27 \mathrm{ng} /$ $\mathrm{m}^{3}$ ). Wilson et al. (2003) reported higher concentrations of naphthalene in indoor air of a preschool (median of $546 \mathrm{ng} / \mathrm{m}^{3}$ ); still these levels were well below the WHO recommended guideline.

There is relatively very little information on indoor PAHs in educational environments (i.e., in preschools and in schools). The reported levels of all studies available in literature are summarized in Table 3. In general, the levels of $\mathrm{PM}_{2.5}$ bound PAHs in this study were similar to those reported from elementary schools in Rome during winter season (Gatto et al., 2013), whereas no information was found on $\mathrm{PM}_{1}$-bound PAHs in indoor air of schools and/or preschools. Concerning gaseous PAHs, the most similar range of concentrations was observed in primary schools in Lithuania (Krugly et al., 2014). Overall, there were very significant differences among the levels and ranges of PAHs reported in the literature for indoor air of educational environments, ranging from $0.28 \mathrm{ng} / \mathrm{m}^{3}$ in Bankok Thailand (Ruchirawat et al., 2006, 2007) to $1040 \mathrm{ng} / \mathrm{m}^{3}$ in North Carolina, USA (Wilson et al., 2003). Certainly, geographical and seasonal influences, meteorological conditions, level of urbanization and development of the surrounding area could account for some of the differences. However, it is necessary to point out that study designs varied greatly between the mentioned works, namely in terms of considered indoor environments (preschool, elementary or primary school), particle size fractions (differing between $\mathrm{PM}_{1}, \mathrm{PM}_{2.5}, \mathrm{PM}_{10}$, TSP, or unspecified), consideration of compounds present in the gas-phase, and the number of individual PAHs compounds analyzed, which can influence the significance of comparisons across studies.

Figure 1 shows the distribution of PAHs between particle and gas-phases in the indoor air of the studied preschool. The distribution of PAHs between the two phases predominantly depends on the physical characteristics of the compounds as well as on the physical conditions of the studied environments such as temperature and RH (Ravindra et al., 2008). Typically, PAHs with higher molecular weight (five and more aromatic rings) are mostly associated with the particle phase, whereas compounds with 2-3 rings are predominantly found in the gas-phase (Guo et al., 2011). As demonstrated in Figure 1, the phase-distribution of PAHs in 


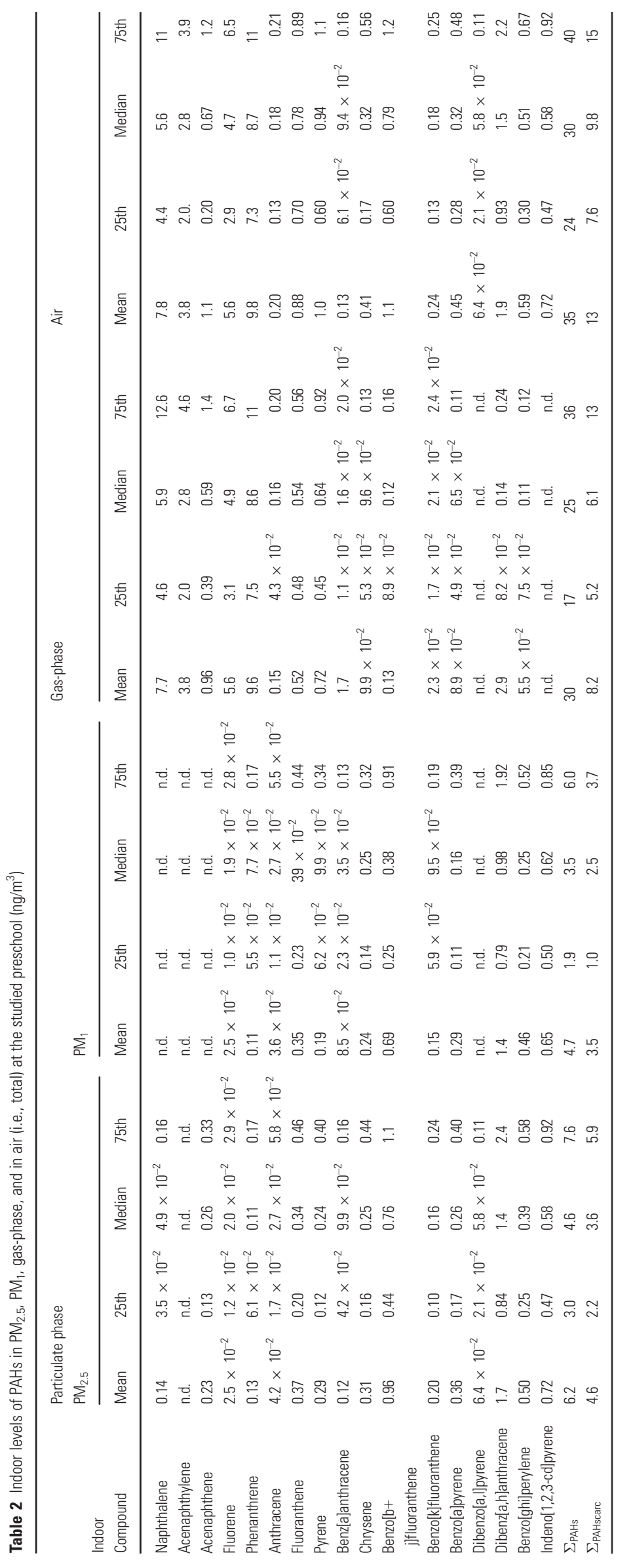


Table 3 Polycyclic aromatic hydrocarbon levels (mean \pm s.d. or range, expressed as $\mathrm{ng} / \mathrm{m}^{3}$ ) reported in indoor and outdoor air of educational environments: comparison with existent studies

\begin{tabular}{|c|c|c|c|c|c|c|c|}
\hline Location & $\begin{array}{l}\text { Type of school } \\
\text { (children age) }\end{array}$ & Note & Analyzed phase & No. of PAHs & $\Sigma$ PAHs indoor & $\Sigma$ PAHs outdoor & Reference \\
\hline Porto, Portugal & Preschool (3-5 years) & Urban & $\begin{array}{l}\mathrm{PM}_{2.5} \\
\mathrm{PM}_{1} \\
\text { Gas-phase } \\
\text { Total air }\end{array}$ & 18 & $\begin{array}{r}0.72-16 \\
0.53-15 \\
14-66 \\
20-82\end{array}$ & $1.2-33$ & This study \\
\hline $\begin{array}{l}\text { Aveiro, Portugal } \\
\text { Linz, Austria }\end{array}$ & $\begin{array}{l}\text { Primary (n.r.) } \\
\text { Elementary (7-10 years) }\end{array}$ & City center & $\begin{array}{l}\mathrm{PM}_{10} \\
\mathrm{PM}_{2.5}\end{array}$ & n.r. & $0.893 \pm 0.650$ & $\begin{array}{c}0.830 \pm 0.421 \\
1.5-174.7\end{array}$ & $\begin{array}{l}\text { Alves et al. (2014) } \\
\text { Moshammer and } \\
\text { Neuberger (2003) }\end{array}$ \\
\hline Campania, Italy & n.r. (7-9 years) & $\begin{array}{l}\text { Urban } \\
\text { Rural }\end{array}$ & Total air (PM + gas) & 16 & $\begin{array}{l}0.30-6.30 \\
1.70-7.90\end{array}$ & $\begin{array}{l}0.3-3.4 \\
0.6-1.4\end{array}$ & Cirillo et al. (2006) \\
\hline Rome, Italy & Elementary (8-11 years) & $\begin{array}{l}\text { Summer } \\
\text { Winter }\end{array}$ & $\mathrm{PM}_{2.5}$ & 8 & $\begin{array}{c}2.21-1.32 \\
1.6-16\end{array}$ & $\begin{array}{r}0.36-2.56 \\
4.2-18.5\end{array}$ & Gatto et al. (2013) \\
\hline Kaunas, Lithuania & Primary (n.r.) & & $\begin{array}{l}\mathrm{PM}_{2.5} \\
\text { Gas }\end{array}$ & 15 & $\begin{array}{c}20.3-131 \\
35.6-80.6\end{array}$ & $\begin{array}{l}40.7-121.1 \\
\text { n.r. }\end{array}$ & Krugly et al. (2014) \\
\hline $\begin{array}{l}\text { North Carolina, USA } \\
\text { Thailand }\end{array}$ & Preschool (2-5 years) & Urban & $\begin{array}{l}\text { Total air (PM + gas) } \\
\text { PM }\end{array}$ & 18 & $0.04-1044$ & $0.04-76.5$ & $\begin{array}{l}\text { Wilson et al. (2003) } \\
\text { Ruchirawat et al. (2006) }\end{array}$ \\
\hline Bangkok & n.r. (9-13 years) & $\begin{array}{l}\text { Classroom } \\
\text { Playground }\end{array}$ & PM-air particulates & & $\begin{array}{l}5.06-9.39 \\
2.64-25.54\end{array}$ & $12.01-99.95$ & Ruchirawat et al. (2007) \\
\hline Bangkok & & $\begin{array}{l}\text { Rural } \\
\text { Classroom } \\
\text { Playground }\end{array}$ & & & $\begin{array}{l}0.28-2.31 \\
0.28-1.92\end{array}$ & $0.31-2.91$ & \\
\hline $\begin{array}{l}\text { Thailand, Bangkok } \\
\text { Bangkok }\end{array}$ & Primary (8-13 years) & $\begin{array}{l}\text { Urban } \\
\text { Rural }\end{array}$ & PM & 10 & & $\begin{array}{l}2.10-25.54 \\
0.28-2.31\end{array}$ & Tuntawiroon et al. (2007) \\
\hline Delhi, India & Primary (n.r.) & $\begin{array}{l}\text { Industrial and } \\
\text { roadside }\end{array}$ & $\mathrm{PM}_{10}$ & 10 & n.r. & $38.1-217.3$ & Jyethi et al. (2014) \\
\hline
\end{tabular}

n.r., not reported.

indoor air of the studied preschool was in agreement with findings of other studies (Possanzini et al., 2004). Compounds with two and three aromatic rings, namely naphthalene, acenapthlylene, fluorene, phenanthrene, were almost entirely present in the gas-phase (i.e., more than $99 \%$ ). On the contrary, PAHs with five rings, namely benzo[b+j]fluoranthene, benzo[k]fluoranthene, benzo[a]pyrene, dibenz[a,h]anthracene, were predominantly bound to particles (i.e., more than 90\%). Compounds with six aromatic rings such as dibenzo[a,l] pyrene and indeno[1,2,3-cd]pyrene were entirely present in particles. Finally, PAHs with four rings that included fluoranthene, pyrene, benz[a]anthracene, and chrysene were distributed between the two phases with the proportions in the gas-phase ranging between 13 and $71 \%$. In that regard, it is necessary to point out that acenapthene (three aromatic rings) exhibited unexpected high distribution in the particle phase (i.e., $19 \%$ ). No reason was identified which could justify this abundance in PM, although unlike other individual PAHs acenapthene was detected only in $51 \%$ of the existent particulate samples and this might contribute to the apparent inconsistency. Overall, the PAH phase distribution of the studied preschool was similar to those of primary schools reported by Krugly et al. (2014); other studies available in literature that included characterization of PAHs in air (i.e., assessment of both gas and particulate phases) in educational settings (Table 3) did not specifically report these findings.

In total, the gaseous PAHs accounted for $85 \%$ of $\Sigma_{\text {PAHs. }}$ This high proportion of PAHs in the gas-phase clearly demonstrates that adequate assessment of PAHs exposure requires consideration of the gaseous compounds, which have commonly been neglected in prior studies.

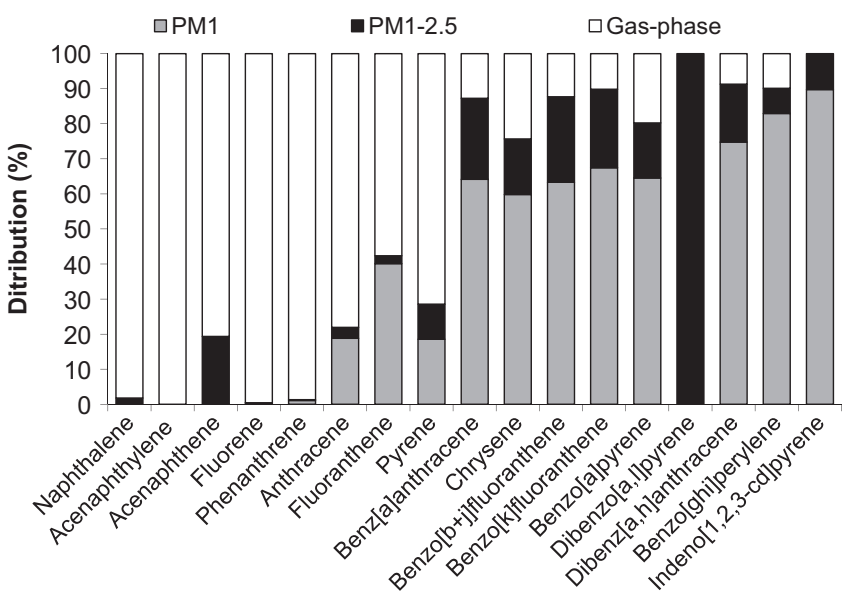

Fig. 1 Distribution of polycyclic aromatic hydrocarbons (PAHs) between particulate and gaseous phases in indoor air of the studied preschool. The particle phase is further divided into $\mathrm{PM}_{1}$ and $\mathrm{PM}_{1-2.5}$ fractions (particles with aerodynamic diameter between 1.0 and $2.5 \mu \mathrm{m}$ ) 
The results in Table 2 and Figure 1 also demonstrate that particulate PAHs were associated with particles of smaller sizes, that is, $\mathrm{PM}_{1}$. For all 18 individual compounds, the proportion in $\mathrm{PM}_{1}$ (in comparison with $\mathrm{PM}_{2.5}$ ) ranged between $65 \%$ (pyrene) and 95\% (fluoranthene). On average, $\mathrm{PM}_{1}$-bound PAHs accounted for $76 \%$ for particulate $\Sigma_{\mathrm{PAHs}}$ whereas PAHs on particles bigger than $1 \mu$ m (i.e., $\mathrm{PM}_{1-2.5}$ ) accounted for $14 \%$ of PAH particulate content. Overall, these results confirmed the previously reported findings that particulate-bound PAHs are predominantly found in smaller fractions of PM (Klejnowski et al., 2010; Ladji et al., 2014). Due to their ability to deposit deep in the lower airways, the smaller classes of PM are more apt to cause respiratory toxicity and dysfunction. Furthermore, various chemical compounds bound to these small particles, such as PAHs, may eventually enhance (or at least contribute to) the PM-induced adverse health effects (Kim et al., 2013; Saravia et al., 2013).

Of 18 analyzed PAHs, naphthalene, benz[a] anthracene, chrysene, benzo[b]fluoranthene, benzo[j] fluoranthene, benzo[k]luoranthene, benzo[a]pyrene, dibenzo[a,l]pyrene, dibenz[a,h]anthracene and indeno [1,2,3-cd]pyrene were reported as carcinogenic ones (possible, probable) (IARC, 2002, 2010). The mean concentrations of these 10 carcinogenic PAHs (i.e., $\Sigma_{\text {PAHscarc }}$ ) in indoor PM, gas-phase, and in indoor air are reported also in Table 2. Dibenz[a,h]anthracene, a strong carcinogen with a toxic equivalency factor (TEF) five times higher than benzo[a]pyrene (Okona-Mensah et al., 2005), was the most abundant carcinogen and accounted for $40 \%$ of $\Sigma_{\text {PAHscarc }}$ Considering the protection of public health, it is important to stress that dibenz[a,h]anthracene exhibited the highest concentrations of all 18 PAHs in both $\mathrm{PM}_{2.5}$ and $\mathrm{PM}_{1}$ in indoor air of the studied preschool, being followed by other carcinogens: benzo[b+j]fluoranthene (20\% of $\left.\Sigma_{\text {PAHscarc }}\right)$ and indeno[1,2,3-cd]pyrene (19 and $16 \%$ of $\Sigma_{\text {PAHscarc }}$ in $\mathrm{PM}_{1}$ and $\mathrm{PM}_{2.5}$, respectively). Finally, benzo[a]pyrene, the most studied and characterized carcinogen (IARC, 2010), was the fifth most abundant particulate (and the fourth most abundant carcinogenic) PAH, contributing $8 \%$ of $\Sigma_{\mathrm{PAHscarc}}$ in both PM size fractions. Concerning the gas-phase, naphthalene was the predominant carcinogenic gaseous PAH (94\% of gaseous $\Sigma_{\text {PAHscarc }}$ ) as the content of other carcinogenic compounds was much less significant (i.e., $0.5-2 \%$ of gaseous $\Sigma_{\text {PAHscarc). }}$.

The total concentration of the carcinogenic PAHs in indoor air of the studied preschool was $13 \mathrm{ng} / \mathrm{m}^{3}$. The obtained results showed that $64 \%$ of $\Sigma_{\text {PAHscarc }}$ existed in the gas-phase whereas $36 \%$ was particle bound. Despite this distribution, carcinogenic PAHs accounted for $27 \%$ of the gaseous PAH content whereas it was $74 \%$ of $\Sigma_{\mathrm{PAHs}}$ in both $\mathrm{PM}_{2.5}$ and $\mathrm{PM}_{1}$; similarly Jyethi et al. (2014) reported that carcinogenic
PAHs accounted for approximately $75 \%$ of the particulate PAH content. Finally, in agreement with the findings on the distribution of PAHs (Figure 1), carcinogenic particulate $\mathrm{PAHs}$ were predominantly associated with $\mathrm{PM}_{1}(76 \%)$.

\section{Outdoor PAHs and source identification}

The levels of PAHs in $\mathrm{PM}_{2.5}$ measured outdoors in the preschool yard are presented in Table 4. Overall, concentration levels of outdoor particulate PAHs were similar to those reported in earlier studies (Castro et al., 2011; Slezakova et al., 2013a,b). The levels registered in ambient air of the selected preschool were much higher compared to other Portuguese and Italian cities (Alves et al., 2014; Cirillo et al., 2006). On the contrary, in close proximity of schools situated in Asian countries authors reported much higher concentrations of particle-bound PAHs (Jyethi et al., 2014; Ruchirawat et al., 2006, 2007) compared to this study. In general, the observed concentrations of outdoor particulate PAHs were higher than the indoor ones, but the compositional profiles were similar. The most abundant compounds were (in descending order) dibenz[a,h]anthracene $\left(25 \%\right.$ of $\left.\Sigma \mathrm{PAH}_{\text {scarc }}\right)$, benzo[b+j] fluoranthene (approximately 15\%), indeno[1,2,3-cd] pyrene $(9 \%)$, and benzo[ghi]perylene $(8 \%)$. Finally, 10 carcinogenic PAHs accounted for $78 \%$ of the particulate PAHs, being similar percentage as indoors.

Indoor-outdoor ratios

Indoor-outdoor concentration ratios $(\mathrm{I} / \mathrm{O})$ of individual PAHs can provide some clues about pollutant's origin. $\mathrm{I} / \mathrm{O}$ ratios of all $18 \mathrm{PM}_{2.5}$-bound $\mathrm{PAHs}$ are

Table 4 Concentrations of $\mathrm{PM}_{2.5}$-bound PAHs in ambient (i.e., outdoor) air of the studied preschool $\left(\mathrm{ng} / \mathrm{m}^{3}\right)$

\begin{tabular}{|c|c|c|c|c|}
\hline Compound & Mean & 25th & Median & 75th \\
\hline Naphthalene & 0.76 & $5.5 \times 10^{-2}$ & $6.9 \times 10^{-2}$ & 0.20 \\
\hline Acenaphthylene & 0.80 & 0.40 & 0.83 & 1.2 \\
\hline Acenaphthene & 0.12 & $3.3 \times 10^{-2}$ & $4.5 \times 10^{-2}$ & 0.18 \\
\hline Fluorene & $5.0 \times 10^{-2}$ & $1.4 \times 10^{-2}$ & $3.1 \times 10^{-2}$ & $3.8 \times 10^{-2}$ \\
\hline Phenanthrene & $0.27 \times 10^{-2}$ & 0.12 & 0.17 & 0.31 \\
\hline Anthracene & 7.1 & $2.7 \times 10^{-2}$ & $5.0 \times 10^{-2}$ & 0.10 \\
\hline Fluoranthene & 0.61 & 0.26 & 0.45 & 1.0 \\
\hline Pyrene & 0.62 & 0.28 & 0.44 & 0.75 \\
\hline Benz[a]anthracene & 0.25 & $7.1 \times 10^{-2}$ & 0.13 & 0.27 \\
\hline Chrysene & 0.60 & 0.27 & 0.33 & 0.76 \\
\hline Benzo[b+j]fluoranthene & 1.3 & 0.39 & 0.86 & 1.7 \\
\hline Benzo[k]fluoranthene & 0.29 & 0.11 & 0.18 & 0.33 \\
\hline Benzo[a]pyrene & 0.49 & 0.15 & 0.31 & 0.57 \\
\hline Dibenzo[a,l]pyrene & $9.8 \times 10^{-2}$ & $5.7 \times 10^{-2}$ & $8.2 \times 10^{-2}$ & 0.12 \\
\hline Dibenz[a,h]anthracene & 2.2 & 0.88 & 1.5 & 2.5 \\
\hline Benzo[ghi]perylene & 0.70 & 0.32 & 0.42 & 0.76 \\
\hline Indeno[1,2,3-cd]pyrene & 0.79 & 0.20 & 0.54 & 0.94 \\
\hline$\Sigma_{\mathrm{PAHs}}$ & 8.9 & 4.0 & 5.5 & 13 \\
\hline$\Sigma_{\text {PAHscarc }}$ & 6.8 & 2.8 & 4.2 & 10 \\
\hline
\end{tabular}




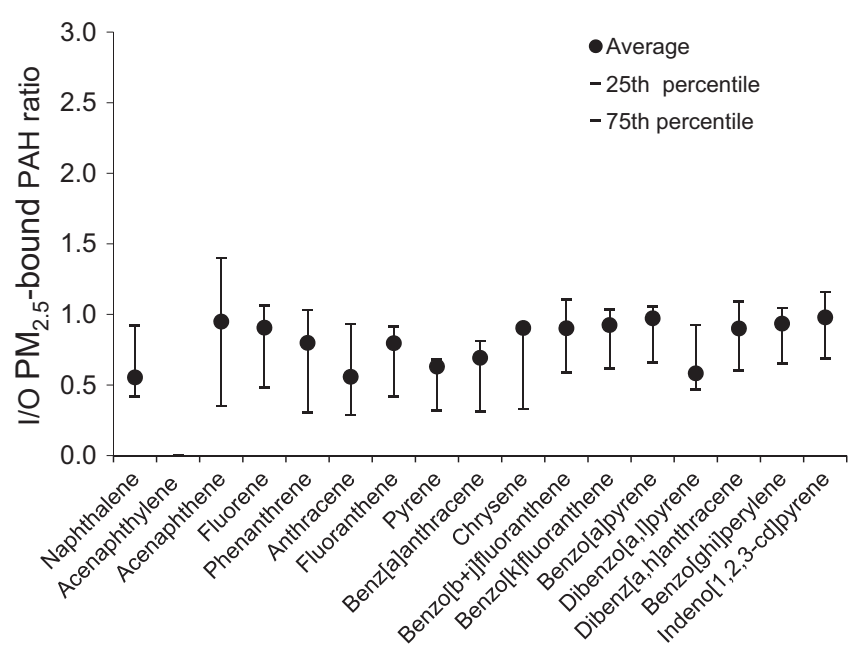

Fig. 2 Indoor-outdoor (I/O) $\mathrm{PM}_{2.5}$-bound polycyclic aromatic hydrocarbon $(\mathrm{PAH})$ ratios at the studied preschool. Midpoints represent average values; whiskers are 25 th and 75 th percentiles

presented in Figure 2. The mean $\mathrm{I} / \mathrm{O}$ ratios of all 18 PAHs were lower than unity suggesting that outdoor air is the dominant contributor to indoor PAH levels at this site. However, on some occasions all 18 PAHs exceeded unity, indicating contributions from indoor sources. Krugly et al. (2014) reported I/O ratio higher than unity for low molecular weight PAHs in indoor air of schools; these authors suggested an indoor origin due the respective activities of the occupants and/or volatilization from building materials. The potential indoor sources registered during the sampling in the studied preschool that could have resulted in elevated PAH content included combustion sources (candles on birthday cake during several occasions; Derudi et al., 2013), children artistic activities during classes (i.e., painting, sculpturing, wax melting, and other arts and crafts activities) and classroom cleaning (wood polishing) (Morawska et al., 2013).

\section{Diagnostic ratios}

The ratio values of individual PAH concentrations were used as diagnostic tools to identify the possible origin of the PAHs. The diagnostic ratios were calculated based on the same particulate fraction $\left(\mathrm{PM}_{2.5}\right)$ for both indoor and outdoor PAHs and means are presented in Table 5. It is necessary to point out that such ratios are crude indicators of possible sources and need to be used with caution; it is often difficult to distinguish between different sources (Galarneau, 2008). Furthermore, their values can be altered due to the reactivity of some PAH species with other atmospheric species (such as ozone and/or oxides of nitrogen; Ravindra et al., 2008). Diagnostic ratios of the total

Table 5 Diagnostic ratios for $\mathrm{PM}_{2.5}$-bound PAHs at the studied preschool

\begin{tabular}{|c|c|c|c|c|c|}
\hline \multirow[b]{2}{*}{ Ratio } & \multicolumn{2}{|c|}{ This study } & \multirow[b]{2}{*}{ Value } & \multirow[b]{2}{*}{ Source } & \multirow[b]{2}{*}{ Reference } \\
\hline & Indoor & Outdoor & & & \\
\hline$\Sigma P A H s_{L M W} / \Sigma P A H s_{H M W}{ }^{a}$ & 0.24 & 0.57 & $\begin{array}{l}>1 \\
<1\end{array}$ & $\begin{array}{l}\text { Petrogenic } \\
\text { Pyrogenic }\end{array}$ & Zhang et al. (2008) \\
\hline Benzo[a]anthracene/Chrysene & 0.38 & 0.42 & $>0.35$ & Fuel combustion & Krugly et al. (2014) \\
\hline Fluoranthene/(Fluoranthene + Pyrene) & 0.54 & 0.50 & $\begin{array}{l}\quad 0.40-0.5 \\
>0.5 \\
0.42,0.52\end{array}$ & $\begin{array}{l}\text { Vehicular traffic } \\
\text { Coal combustion } \\
\text { Road dust }\end{array}$ & $\begin{array}{l}\text { Kavouras et al. (1999), Yunker et al. (2002) } \\
\text { Zencak et al. (2007), Rogge et al. (1993a), Oda et al. (2001) }\end{array}$ \\
\hline $\begin{array}{l}\text { Indeno[1,2,3-cd]pyrene/ } \\
\text { (Indeno[1,2,3-cd]pyrene + Benzo[ghi]perylene) }\end{array}$ & 0.59 & 0.52 & $\begin{array}{l}0.21-0.22 \\
0.35-0.70 \\
0.56 \\
0.62 \\
0.36\end{array}$ & $\begin{array}{l}\text { Gasoline cars } \\
\text { Diesel emissions } \\
\text { Coal combustion } \\
\text { Wood combustion } \\
\text { Road dust }\end{array}$ & $\begin{array}{l}\text { Guo et al. (2003), Grimmer et al. (1983), Gogou et al. (1996), } \\
\text { Kavouras et al. (2001), Khalili et al. (1995), } \\
\text { Ravindra et al. (2008), Rogge et al. (1993a), Pio et al. (2001) }\end{array}$ \\
\hline Benzo[a]pyrene/(Benzo[a]pyrene + Chrysene) & 0.54 & 0.45 & $\begin{array}{l}0.5 \\
0.73\end{array}$ & $\begin{array}{l}\text { Diesel } \\
\text { Gasoline }\end{array}$ & Ravindra et al. (2008) \\
\hline Benzo[b]fluoranthene/Benzo[k]fluoranthene & 4.72 & 4.64 & $>0.5$ & Diesel & Ravindra et al. (2008) \\
\hline Benzo[ghi]perylene/Benzo[a]pyrene & 1.38 & 1.44 & $\begin{array}{l}1.2-2.2 \\
2.5-3.3 \\
0.86,0.91\end{array}$ & $\begin{array}{l}\text { Diesel cars } \\
\text { Gasoline cars } \\
\text { Road dust }\end{array}$ & Rogge et al. (1993a,b), Oda et al. (2001) \\
\hline $\begin{array}{l}\text { Benzo[a]anthracene/ } \\
\text { (Benzo[a]anthracene + chrysene) }\end{array}$ & 0.27 & 0.30 & $\begin{array}{l}0.40,0.38-0.64 \\
0.76 \\
0.43\end{array}$ & $\begin{array}{l}\text { Diesel } \\
\text { Gasoline } \\
\text { Wood combustion }\end{array}$ & Manoli et al. (2004), Sicre et al. (1987), Li and Kamens (1993) \\
\hline Benzo[b+k]Fluoranthene/Benzo[ghi]perylene & 1.36 & 1.75 & $\begin{array}{l}1.60 \\
0.33 \\
2.18\end{array}$ & $\begin{array}{l}\text { Diesel cars } \\
\text { Gasoline cars } \\
\text { Wood combustion }\end{array}$ & Li and Kamens (1993) \\
\hline Fluorene/(Fluorene + Pyrene) & 0.08 & 0.07 & $\begin{array}{l}>0.5 \\
<0.5\end{array}$ & $\begin{array}{l}\text { Diesel } \\
\text { Gasoline }\end{array}$ & Ravindra et al. (2008) \\
\hline Phenanthrene/(Phenanthrene + Anthracene & 0.75 & 0.79 & $>0.7$ & Lubricant oils and fossil fuels & Mirante et al. (2013) \\
\hline
\end{tabular}

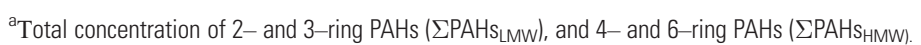


concentration of 2- and 3-rings PAHs ( $\left.2 \mathrm{PAHs} \mathrm{LMw}_{\mathrm{LMW}}\right)$ to 4- and 6-ring PAHs ( $\Sigma \mathrm{PAHs}_{\mathrm{HMW}}$ ) indicate if the origin of PAHs is pyrogenic or petrogenic. In case of ratio bigger than 1, a possible source of PAHs is petrogenic; otherwise the source may be considered as pyrogenic (Krugly et al., 2014; Zhang et al., 2008). In the studied preschool, these diagnostic ratios in both indoors and outdoors were lower than 1, indicating a pyrogenic origin of the PAHs as reported in previous studies; Slezakova et al. (2013b) identified emissions from vehicle road transport as the main sources of PAHs in Oporto. The road traffic was the most likely source of PAHs at the studied preschool; in agreement, the ratio of benzo[a]anthracene to chrysene was lower than 0.35 , indicating combustion of fuel and/or vehicular emissions (Krugly et al., 2014). The ratio value of fluoranthene to (fluoranthene plus pyrene) suggests potential origin from vehicular traffic (Kavouras et al., 1999; Yunker et al., 2002; Zencak et al., 2007) but also possibly from coal combustion (Krugly et al., 2014). Similarly, the ratio indeno[1,2,3-cd]pyrene/(indeno [1,2,3-cd]pyrene+benzo[ghi]perylene), with values in range $0.35-0.70$, indicates influence by diesel emissions (Kavouras et al., 2001; Rogge et al., 1993a; Sicre et al., 1987), as close to 0.56 it might suggest origin from coal combustion (Grimmer et al., 1983; Pio et al., 2001). Other ratios that were applied to the obtained PAHs levels in the studied preschool were indicative of vehicular influence. Ravindra et al. (2008) reported a ratio of benzo[a]pyrene to (benzo[a]pyrene plus chrysene) to distinguish between diesel (0.5) and gasoline (0.73) vehicle emissions. In addition, benzo[b]fluoranthene to benzo[k]fluoranthene ratios higher than 0.5 (Ravindra et al., 2008) and benzo[ghi]perylene/benzo[a]pyrene with values between 1.2 and 2.2 (Rogge et al., 1993a) also indicate diesel emissions. The comparison of the data in Table 5 with values of these three ratios, but also with ratios of benzo[b+k]fluoranthene and benzo [ghi]perylene shows that diesel motor emissions were a source of particulate PAHs at the studied preschool. These findings are in agreement with patterns of fuel consumption in Portugal: diesel is the most used car fuel - in 2011, it accounted for $78.4 \%$ of the total national car fuel consumption (National Institute of Statistics, 2013). The ratio of fluorene/(fluorene+pyrene) is typically also used to differentiate between diesel and gasoline exhausts. Whereas values $>0.5$ indicate contribution from diesel emissions, ratios $<0.5$ indicate gasoline emissions (Ravindra et al., 2008; Rogge et al., 1993a); the present result shows very low values of this diagnostic ratio thus suggesting some presence of gasoline emissions. Finally, phenanthrene/(phenanthrene+anthracene) ratio exhibited values higher than 0.7 , which are characteristic of contributions from lubricant oils and fossil fuels (Mirante et al., 2013). In general, it is possible to conclude that most of the observed PAH diagnostic ratios indicated traffic (with a predominant contribution of diesel) and fossil fuel (with contribution of coal) combustion as the main sources of PAHs in the studied preschool.

\section{Conclusions}

This study fills a gap providing information on the PAH levels and phase distribution in indoor air in a preschool environment. Little information was available for school or for preschool facilities especially with regard to gaseous compounds or PAHs bound to the finest PM. In total, the gaseous PAHs accounted for $85 \%$ of $\Sigma_{\text {PAHs }}$. This high proportion of PAHs in the gas-phase clearly demonstrates that adequate assessment of PAHs exposure requires consideration of the gaseous compounds, which are in the most of the studies neglected. Particulate, PAHs were predominantly associated with $\mathrm{PM}_{1}(76 \%$ particulate $\Sigma \mathrm{PAHs})$ with five rings PAHs being the most abundant. The use of various diagnostic ratios determined two main sources of indoor PAHs: traffic emissions and the combustion of fossil fuel, as a consequence of penetration of outdoors into the indoor air.

Children represent one of the most vulnerable groups in society. To provide better information for the protection of their health, the future work should focus on the characterizing PAH exposure of children, also considering various school microenvironments.

\section{Acknowledgements}

This work was supported by Fundação para Ciência e Tecnologia through fellowships SFRH/BD/80113/ 2011, SFRH/BPD/65722/2009, and by the IJUP project PP_IJUP2011 121. It also received financial support from the European Union (FEDER funds through COMPETE) and National Funds (Fundação para a Ciência e Tecnologia) through projects Pest-C/ EQB/LA0006/2013 and PEst-C/EQB/UI0511/2013.

\section{Supporting Information}

Additional Supporting Information may be found in the online version of this article:

Table S1. Characteristics of the studied indoor environment at the preschool.

Figure S1. Characterization of the indoor environment at the sampled preschool: (a) schematic layout; and (b) photographic demonstration. 


\section{References}

Alves, C.A., Urban, R.C., Pegas, P.N. and Nunes, T. (2014) Indoor/Outdoor relationships between PM10 and associated organic compounds in a primary school, Aerosol. Air Qual. Res., 14, 86-98.

Annesi-Maesano, I., Moreau, D., Caillaud, D., Lavaud, F., Le Moullec, Y., Taytard, A., Pauli, G. and Charpin, D. (2007) Residential proximity fine particles related to allergic sensitisation and asthma in primary school children, Respir. Med., 101, 1721-1729.

Bae, S., Pan, X.-C., Kim, S.-Y., Park, K., Kim, Y.-H., Kim, H. and Hong, Y.-C. (2010) Exposures to particulate matter and polycyclic aromatic hydrocarbons and oxidative stress in schoolchildren, Environ. Health Perspect., 118, 579-583.

Burtscher, H. and Schüepp, K. (2012) The occurrence of ultrafine particles in the specific environment of children, Paediatr. Respir. Rev., 13, 89-94.

Castro, D., Slezakova, K., Oliva-Teles, M.T., Delerue-Matos, C., Alvim-Ferraz, M.C., Morais, S. and Pereira, M.C. (2009) Analysis of polycyclic aromatic hydrocarbons in atmospheric particulate samples by microwave-assisted extraction and liquid chromatography, J. Sep. Sci., 32, 501-510.

Castro, D., Slezakova, K., Delerue-Matos, C., Alvim-Ferraz, M., Morais, S. and Pereira, M.C. (2011) Polycyclic aromatic hydrocarbons in gas and particulate phases of indoor environment influenced by tobacco smoke: levels, phase distribution and health risks, Atmos. Environ., 45, 1799-1808.

Chen, C., Zhao, B., Zhou, W.T., Jiang, X.Y. and Tan, Z.C. (2012) A methodology for predicting particle penetration factor through cracks of windows and doors for actual engineering application, Build. Environ., 47, 339-348.

Cirillo, T., Montuori, P., Mainardi, P., Russo, I., Triassi, M. and Amodio-Cocchieri, R. (2006) Multipathway polycyclic aromatic hydrocarbon and pyrene exposure among children living in Campania (Italy), J. Environ. Sci. Health A Tox. Hazard. Subst. Environ. Eng., 41, 2089 2107.

Decreto Lei 118/2013 (2013) Sistema de certificação energética dos edifícios, o regulamento de desempenho Energético dos Edifí-cios de Habitação e o Regulamento de Desempenho Energético dos Edifícios de comércio e serviços, Diário da Republica 1 série, A 235, 6644(2)-6644(9).

Derudi, M., Gelosa, S., Sliepcevich, A., Cattaneo, A., Cavallo, D., Rota, R. and Nano, G. (2013) Emission of air pollutants from burning candles with different composition in indoor environments, Environ. Sci. Pollut. Res., 21, 4320-4330.
Directive 2004, 107, EC (2005) Directive of the European Parliament and of the Council relating to arsenic, cadmium, mercury, nickel and polycyclic aromatic hydrocarbons in ambient air, Off. J. Eur. Union, L23, 3-16.

Directive 2008/50/EC of the European Parliament and of the Council on ambient air quality and cleaner air for Europe, Off. J. Eur. Union, L152, 1-44.

Galarneau, E. (2008) Source specificity and atmospheric processing of airborne PAHs: implications for source apportionment, Atmos. Environ., 42, 81398149.

Gatto, M.P., Gariazzo, C., Gordiani, A., L'Episcopo, N. and Gherardi, M. (2013) Children and elders exposure assessment to particle-bound polycyclic aromatic hydrocarbons (PAHs) in the city of Rome, Italy, Environ. Sci. Pollut. Res. Int. doi: 10.1007/s11356-013-2442-y (in press).

Ginsberg, G., Asgharian, B., Kimbell, J.S., Ultman, J.S. and Jarabek, A.M. (2008) Modelling approaches for estimating the dosimetry of inhaled toxicants in children, J. Toxicol. Environ. Health Part A, 71, 166-195.

Gogou, A., Stratigakis, N., Kanakidou, M. and Stefanou, E.G. (1996) Organic aerosols in Eastern Mediterranean: components source reconciliation by using molecular markers and atmospheric back trajectories, Org. Geochem., 25, 79-96.

Grimmer, G., Jacob, J., Naujack, K.W. and Dettbarn, G. (1983) Determination of polycyclic aromatic compounds emitted from brown-coal-fired residential stoves by gas chromatography/gas spectrometry, Anal. Chem., 55, 892-900.

Guo, H., Lee, S.C., Ho, K.F., Wang, X.M. and Zou, C. (2003) Particle-associated polycyclic aromatic hydrocarbons in urban air of Hong Kong, Atmos. Environ., 37, 5307-5317.

Guo, H., Morawska, L., He, C., Zhang, Y.L., Ayoko, G. and Cao, M. (2010) Characterization of particle number concentrations and PM2.5 in a school: influence of outdoor air pollution on indoor air, Environ. Sci. Pollut. Res. Int., 17, 1268-1278.

Guo, Y., Wu, K., Huo, X. and Xu, X. (2011) Sources, distribution, and toxicity of polycyclic aromatic hydrocarbons, J. Environ. Health, 73, 22-25.

Hanedar, A., Alp, K., Kaynak, B. and Avşar, E. (2014) Toxicity evaluation and source apportionment of Polycyclic Aromatic Hydrocarbons (PAHs) at three stations in Istanbul, Turkey, Sci. Total Environ., 488-489, 437-446.

IARC Working Group on the Evaluation of Carcinogenic Risks to Humans (2002) Some traditional herbal medicines, some mycotoxins, naphthalene and styrene,
IARC Monogr. Eval. Carcinog. Risks Hum., 82, 1-556.

IARC Working Group on the Evaluation of Carcinogenic Risks to Humans (2010) Some non-heterocyclic polycyclic aromatic hydrocarbons and some related exposures, IARC Monogr. Eval. Carcinog. Risks Hum., 92, 1-853.

Jyethi, D.S., Khillare, P.S. and Sarkar, S. (2014) Risk assessment of inhalation exposure to polycyclic aromatic hydrocarbons in school children, Environ. Sci. Pollut. Res., 21, 366-378.

Kavouras, I.G., Lawrence, J., Koutrakis, P., Stephanou, E.G. and Oyola, P. (1999) Measurement of particulate aliphatic and polynuclear aromatic hydrocarbons in Santiago de Chile: source reconciliation and evaluation of sampling artifacts, Atmos. Environ., 33, 4977-4986.

Kavouras, I.G., Koutrakis, P., Tsapakis, M., Lagoudaki, E., Stephanou, E.G., Von Baer, D. and Oyola, P. (2001) Source apportionment of urban particulate aliphatic and polynuclear aromatic hydrocarbons (PAHs) using multivariate methods, Environ. Sci. Technol., 35, 2288-2294.

Khalili, N.R., Scheff, P.A. and Holsen, T.M. (1995) PAH source fingerprints for coke ovens, diesel and gasoline engines, highway tunnels, and wood combustion emissions, Atmos. Environ., 29, 533-542.

Kim, K.H., Jahan, S.A., Kabir, E. and Brown, R.J. (2013) A review of airborne polycyclic aromatic hydrocarbons (PAHs) and their human health effects, Environ. Int., 60, 71-80.

Klejnowski, K., Kozielska, B., Krasa, A. and Rogula-Kozlowska, W. (2010) Polycyclic aromatic hydrocarbons in PM1, PM2.5, PM10 and TSP in the upper Silesian agglomeration, Pol. Arch. Environ. Protect., 36, 65-72.

Krugly, E., Martuzevicius, D., Sidaraviciute, R., Ciuzas, D., Prasauskas, T., Kauneliene, V., Stasiulaitiene, I. and Kliucininkas, L. (2014) Characterization of particulate and vapor phase polycyclic aromatic hydrocarbons in indoor and outdoor air of primary schools, Atmos. Environ., 82, 298-306.

Ladji, R., Yassaa, N., Balducci, C. and Cecinato, A. (2014) Particle size distribution of n-alkanes and polycyclic aromatic hydrocarbons (PAHS) in urban and industrial aerosol of Algiers, Algeria, Environ. Sci. Pollut. Res., 21, 1819-1832.

Li, C.K. and Kamens, R.M. (1993) The use of polycyclic aromatic hydrocarbons as source signatures in receptor modelling, Atmos. Environ., 27, 523-532.

Manoli, E., Kouras, A. and Samara, C. (2004) Profile analysis of ambient and source emitted particle-bound polycyclic 
aromatic hydrocarbons from three sites in northern Greece, Chemosphere, 56, 867-878.

Miller, J.N. and Miller, J.C. (2000) Statistics for Analytical Chemistry, Harlow, Pearson Education Ltd.

Mirante, F., Alves, C., Pio, C., Pindado, O., Perez, R., Revuelta, M.A. and Artiñano, B. (2013) Organic composition of size segregated atmospheric particulate matter, during summer and winter sampling campaigns at representative sites in Madrid, Spain, Atmos. Res., 132-133, 345-361.

Morawska, L., Afshari, A., Bae, G.N., Buonanno, G., Chao, C.Y.H., Hänninen, O., Hofmann, W., Isaxon, C., Jayaratne, E.R., Pasanen, P., Salthammer, T., Waring, M. and Wierzbicka, A. (2013) Indoor aerosols: from personal exposure to risk assessment, Indoor Air, 23, 462-487.

Moshammer, H. and Neuberger, M. (2003) The active surface of suspended particles as a predictor of lung function and pulmonary symptoms in Austrian school children, Atmos. Environ., 37, 1737-1744.

National Institute of Statistics (2013) Statistical Yearbook of Portugal 2012. National Institute of Statistics, Lisbon. Available at: http://www.ine.pt/xportal/ xmain?xpid = INE\&xpgid =ine_publicacoes\&PUBLICACOESpub_boui $=20957$ 0943\&PUBLICACOEStema $=55480 \&$ PUBLICACOESmodo $=2 \&$ xlang $=$ en.

Oda, J., Nomura, S., Yasuhara, A. and Shibamoto, T. (2001) Mobile sources of atmospheric polycyclic aromatic hydrocarbons in a roadway tunnel, Atmos. Environ., 35, 4819-4827.

Okona-Mensah, K.W., Battershill, J., Boobis, A. and Fielder, R. (2005) An approach to investigating the importance of high potency polycyclic aromatic hydrocarbons (PAHs) in the induction of lung cancer by air pollution, Food Chem. Toxicol., 43, 1103-1116.

Pio, C.A., Alves, C.A. and Duarte, A.C. (2001) Identification, abundance and origin of atmospheric organic particulate matter in a Portuguese rural area, Atmos. Environ., 35, 1365-1375.

Possanzini, M., Di Palo, V., Gigliucci, P., Tomasi Sciano, M.C. and Cecinato, A. (2004) Determination of phase-distributed PAH in Rome ambient air by denuder/ GC-MS method, Atmos. Environ., 38, 1727-1734.

Pufulete, M., Battershill, J., Boobis, A. and Fielder, R. (2004) Approaches to carcinogenic risk assessment for polycyclic aromatic hydrocarbon: a UK perspective, Regul. Toxicol. Pharmacol., 40, 54-56.

Qi, H., Li, W.-L., Zhu, N.-Z., Ma, W.-L., Liu, L.-Y., Zhang, F. and Li, Y.-F.
(2014) Concentrations and sources of polycyclic aromatic hydrocarbons in indoor dust in China, Sci. Total Environ., 491-492, 100-107.

Ravindra, K., Sokhi, R. and Grieken, R.V. (2008) Atmospheric polycyclic aromatic hydrocarbons: source attribution, emission factors and regulation, Atmos. Environ., 42, 2895-2921.

Rogge, W.F., Hildemann, L.M., Mazurek, M.A., Cass, G.R. and Simoneit, B.R.T. (1993a) Sources of fine organic aerosol. 2. Noncatalyst and catalystequipped automobiles and heavy-duty diesel trucks, Environ. Sci. Technol., 27, 636-651.

Rogge, W.F., Hildemann, L.M., Mazurek, M.A., Cass, G.R. and Simoneit, B.R.T. (1993b) Sources of fine organic aerosol. 3 . Road dust, tire debris and organometallic brake lining dust: roads as sources and sinks, Environ. Sci. Technol., 27, 1892-1904.

Ruchirawat, M., Navasumrit, P., Settachan, D. and Autrup, H. (2006) Environmental impacts on children's health in Southeast Asia: genotoxic compounds in urban air, Ann. N. Y. Acad. Sci., 1076, 678-690.

Ruchirawat, M., Settachan, D., Navasumrit, P., Tuntawiroon, J. and Autrup, H. (2007) Assessment of potential cancer risk in children exposed to urban air pollution in Bangkok, Thailand, Toxicol. Lett., 168, 200-209.

Saravia, J., Lee, G.I., Lomnicki, S., Dellinger, B. and Cormier, S.A. (2013) Particulate matter containing environmentally persistent free radicals and adverse infant respiratory health effects: a review, J. Biochem. Mol. Toxicol., 27, 56-68.

Shen, G., Wei, S., Zhang, Y., Wang, R., Wang, B., Li, W., Shen, H., Huang, Y., Chen, Y., Chen, H., Wei, W. and Tao, S. (2012) Emission of oxygenated polycyclic aromatic hydrocarbons from biomass pellet burning in a modern burner for cooking in China, Atmos. Environ., 60, 234-237.

Sicre, M.A., Marty, J.C., Saliot, A., Aparicio, X., Grimalt, J. and Albaiges, S. (1987) Aliphatic and aromatic hydrocarbons in different sized aerosols over the Mediterranean Sea: occurrence and origin, Atmos. Environ., 21, 2247-2259.

Slezakova, K., Castro, D., Pereira, M.C., Morais, S., Delerue-Matos, C. and Alvim-Ferraz, M.C. (2009) Influence of tobacco smoke on carcinogenic PAH composition in indoor PM10 and PM2.5, Atmos. Environ., 43, 6376-6382.

Slezakova, K., Castro, D., Delerue-Matos, C., Alvim-Ferraz, M.C., Morais, S. and Pereira, M.C. (2013a) Impact of vehicular traffic emissions on particulate-bound PAHs: Levels and associ- ated health risks, Atmos. Res., 127, 141-147.

Slezakova, K., Pires, J.C.M., Castro, D., Alvim-Ferraz, M.C.M., Delerue-Matos, C., Morais, S. and Pereira, M.C. (2013b) $\mathrm{PAH}$ air pollution at a Portuguese urban area: carcinogenic risks and sources identification, Environ. Sci. Pollut. Res., 20, 3932-3945.

Slezakova, K., Castro, D., Delerue-Matos, C., Morais, S. and Pereira, M.C. (2014) Levels and risks of particulate-bound PAHs in indoor air influenced by tobacco smoke: a field measurement, Environ. Sci. Pollut. Res., 21, 4492-4501.

Tuntawiroon, J., Mahidol, C., Navasumrit, P., Autrup, H. and Ruchirawat, M. (2007) Increased health risk in Bangkok children exposed to polycyclic aromatic hydrocarbons from trafficrelated sources, Carcinogenesis, 28, 816-822.

USEPA (United States Environmental Protection Agency) (2005) Guidelines for carcinogen risk assessment, EPA/630/P-03/ $001 F$, Washington, D. C., USA, US Environmental Protection Agency, Available at: http://www.epa.gov/raf/publications/pdfs/CANCER_GUIDELINES_ FINAL_3-25-05.pdf.

Wilson, N.K. ., Chuang, J.C., Lyu, C., Menton, R. and Morgan, M.K. (2003) Aggregate exposures of nine preschool children to persistent organic pollutants at day care and at home, J. Expo. Anal. Environ. Epidemiol., 13, 187-202.

World Health Organization (2010) WHO Guidelines for Indoor Air Quality: Selected Pollutants, Copenhagen, Denmark, Regional Office for Europe of the World Health Organization.

World Health Organization (2013) State of the Science of Endocrine Disrupting Chemicals 2012, Geneva, United Nations Environment Programme and the World Health Organization.

Yunker, M.B., Macdonald, R.W., Vingarzan, R., Mitchell, R.H., Goyette, D. and Sylvestre, S. (2002) PAHs in the Fraser River basin: a critical appraisal of $\mathrm{PAH}$ ratios as indicators of $\mathrm{PAH}$ source and composition, Org. Geochem., 33, 489515.

Zencak, Z., Klanova, J., Holoubek, I. and Gustafsson, Ö. (2007) Source apportionment of atmospheric PAHs in the Western Balkans by natural abundance radiocarbon analysis, Environ. Sci. Technol., 41, 3850-3855.

Zhang, W., Zhang, S., Wan, C., Yue, D., Ye, Y. and Wang, X. (2008) Source diagnostics of polycyclic aromatic hydrocarbons in urban road runoff, dust, rain and canopy through fall, Environ. Pollut., 153, 594-601. 